\title{
Biologi Penggerek Batang Jagung Ostrinia furnacalis Gueneé yang diberi Pakan Buatan
}

\section{Biology of Corn-borer Ostrinia furnacalis Guenée Fed by Artificial Diet}

\author{
Arif Mukhtar Hasbi ${ }^{1}$, Rika Raffiudin ${ }^{1 *}$, I Made Samudra ${ }^{2}$ \\ ${ }^{1}$ Departemen Biologi, Fakultas MIPA Institut Pertanian Bogor \\ Jl. Raya Darmaga Kampus IPB Darmaga Bogor 16680, Jawa Barat, Indonesia \\ ${ }^{2}$ Balai Besar Penelitian dan Pengembangan Bioteknologi dan Sumber Daya Genetik Pertanian, \\ Cimanggu, Bogor 16680, Indonesia
}

Diterima 29 April 2016/Disetujui 23 Mei 2016

\begin{abstract}
Ostrinia furnacalis is a corn stem-borer that develops complete metamorphosis and all stages in life cycle in corn. This research was aimed to examine several biology aspects of $O$. furnacalis such as life cycle, egg incubaton period, egg fertility, female fecundity, longevity of imago, and copulation time on artificial diet, based on the previous study. The results of the observations showed that the life cycle of artificial-diet-given $O$. furnacalis was between 27-34 days range. Female fecundity was 16-452 eggs with fertility rate of $61,97 \%$ and 3-5 days renge of egg incubation period. Longevity of imago was between 6-11 days range, and the longevity was longer in female compared to the male. The imago of $O$. furnacalis copulate on 0-3 days after emerge from pupae and the highest number in on the day 1. Copulation time was occurred at 3-8 hour after scotophase commenced and the highest was at third hour. The artificial diet used in this research can be used for $O$. furnacalis mass rearing purpose and performed shorter length of egg stage until pupal stage compared to mass rearing with natural diet.
\end{abstract}

Keywords: maize stem-borer, artificial diet, life cycle, fecundity, longevity, copulation time

\section{PENDAHULUAN}

Ostrinia furnacalis (Lepidoptera: Crambidae) merupakan serangga penggerek batang jagung (Zea mays) dengan distribusi di seluruh Asia Tenggara, Asia Tengah, Asia Timur, dan Australasia (Kalshoven 1981). Ostrinia furnacalis merupakan serangga holometabola karena dalam siklus hidupnya mengalami metamorfosis sempurna. Siklus hidupO. furnacalis terdiri dari stadia telur, larva, pupa, dan imago (ngengat).

Ostrinia furnacalis banyak diteliti karena perannya yang penting sebagai serangga penggerek batang jagung. Oleh karena itu diperlukan metode perbanyakan (mass rearing). Perbanyakan serangga di laboratorium umumnya menggunakan pakan buatan, karena pakan buatan dinilai dapat menghasilkan serangga dengan kebugaran yang lebih baik dibandingkan dengan pakan alami (Rahayu 2014). Pakan buatan dapat menentukan keberhasilan perbanyakan, sehingga penggunaan pakan buatan sangat membantu untuk menemukan cara perbanyakan yang paling baik. Selain itu, penggunaan pakan buatan juga bermanfaat untuk

*Penulis korespondensi. phone/fax: +628121106872 E-mail: rraffiudin@gmail.com pengembangan penelitian yang berkaitan dengan $O$. furnacalis, contohnya penelitian pada bidang fisiologi serangga ini.

Beberapa aspek biologi $O$. furnacalis yang diteliti pada penelitian ini adalah siklus hidup, kemampuan menghasilkan telur (fekunditas), jumlah telur fertil (fertilitas), lama hidup (longivitas), dan waktu kopulasi. Stadia telur $O$. furnacalis yang diberikan pakan alami berupa bagian tanaman jagung berlangsung selama 3-4 hari, stadia larva selama 17-30 hari, stadia pupa selama 7-9 hari, dan stadia imago selama 2-7 hari. Stadia larva terdiri dari lima instar dengan lama masingmasing instar berkisar antara 1-5 hari. Dengan demikian, siklus hidup dari telur hingga menjadi ngengat adalah 27-46 hari dengan rata-rata 37,50 hari (Nonci 2004).

Ngengat $O$. furnacalis digolongkan ke dalam serangga nokturnal, yaitu serangga yang aktif pada malam hari. Proses kopulasi $O$. furnacalis terjadi saat malam hari, yaitu setelah matahari terbenam hingga menjelang matahari terbit. Serangga betina akan menunjukkan perilaku memanggil (calling behaviour) terhadap serangga jantan sebelum melakukan kopulasi. Hal ini juga dilakukan oleh serangga penggerek batang padi kuning (Scirpophaga incertulas) (Nishe 2012). 
Penelitian yang lebih spesifik mengenai waktu $O$. furnacalis melakukan kopulasi belum dilakukan di Indonesia hingga saat ini. Oleh karena itu penelitian ini diperlukan untuk mengetahui waktu seksual aktif $O$. furnacalis populasi Indonesia. Informasi tentang waktu kopulasi $O$. furnacalis juga dapat dimanfaatkan sebagai biokontrol serangga melalui metode penghambatan kawin (mating disruption) dengan menggunakan feromon sintetik.

\section{BAHAN DAN METODE}

Koleksi Ostrinia furnacalis dari lapangan. Ngengat $O$. furnacalis dikoleksi saat stadia larva atau pupa (tergantung saat ditemukan) dari lahan pertanaman jagung di Desa Bantar Kambing, Kecamatan Rancabungur, Kabupaten Bogor. Larva atau pupa O. furnacalis ditemukan pada tanaman inang yang terdapat gejala tinggal O. furnacalis (Gambar 1). Gejala tersebut berupa sisa hasil gerekan dari lubang gerek yang terdapat pada bagian batang dan tongkol jagung (Heryana 2013). Larva atau pupa yang diambil disimpan di dalam kotak plastik $\left(30 \times 15 \times 5 \mathrm{~cm}^{3}\right)$ untuk dibawa ke BB Biogen.

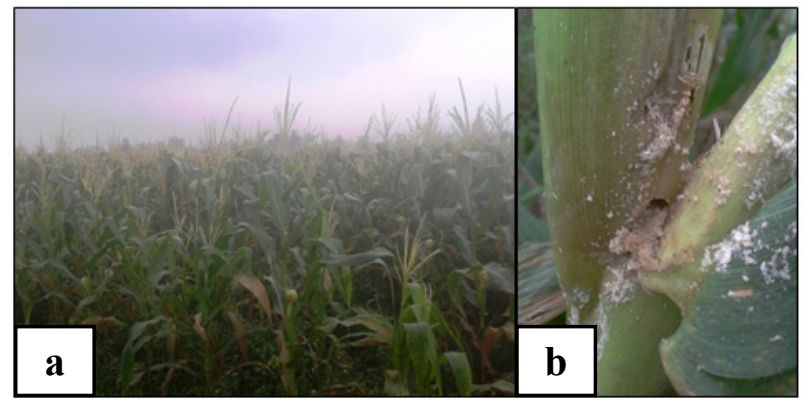

Gambar 1 Kondisi lapangan tempat koleksi O. furnacalis (a) lahan pertanaman jagung di Desa Bantar Kambing (b) gejala tanaman jagung yang terserang $O$. furnacalis.

Perbanyakan $O$. furnacalis dengan pakan buatan. Larva $O$. furnacalis ditempatkan di dalam kotak plastik $\left(30 \times 15 \times 5 \mathrm{~cm}^{3}\right)$ yang sudah diberi alas dan lipatan kertas (Gambar 2a). Pakan buatan (250 g kacang jogo, $200 \mathrm{~g}$ dedak gandum, $48 \mathrm{~g}$ agar kertas, $200 \mathrm{ml}$ air, $125 \mathrm{ml}$ fermipan, $100 \mathrm{~g}$ kasein, $0.025 \mathrm{~g}$ streptomisin, $10 \mathrm{~g}$ vitamin mix, $12 \mathrm{~g}$ L-ascorbic acid, $6 \mathrm{~g}$ sorbic acid, $10 \mathrm{~g}$ vitamin B Kompleks), diletakkan di dalam kotak dan ditutup dengan kain kasa. Ketersediaan dan kondisi pakan diperiksa setiap hari dan pakan harus segera diganti jika sudah terlihat kering. Komposisi $1 \mathrm{~kg}$ pakan buatan yang digunakan terdiri dari tepung kacang jogo, dedak gandum, ragi, agar kertas, vitamin L-Ascorbic acid, vitamin sorbic acid, vitamin B kompleks, antibiotik (Streptomycine), dan air. Larva dipelihara di dalam kotak hingga menjadi pupa. Pupa dipindahkan ke dalam toples plastik dengan diameter $12 \mathrm{~cm}$ dan tinggi $20 \mathrm{~cm}$ yang permukaan bagian dalamnya telah dilapisi kertas sebagai media bertelur imago (Gambar 2b). Kapas yang sudah diresapi larutan madu $10 \%$ ditempatkan di dalam toples sebagai sumber makanan untuk imago. Telur yang dihasilkan pasangan imago dipindahkan ke dalam kotak plastik lain dan diberikan kondisi yang sama hingga menjadi pupa. Hal ini dilakukan terus menerus sebanyak lima kali daur hidup sampai didapatkan jumlah $O$. furnacalis yang mencukupi, yaitu sekitar 3000 ekor.

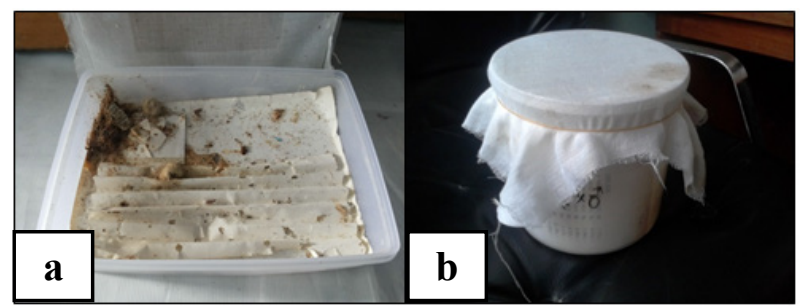

Gambar 2 Wadah untuk perbanyakan $O$. furnacalis (a) kotak pemeliharaan stadia telur hingga larva (b) toples pemeliharaan imago hingga menghasilkan telur.

\section{Pengamatan biologi Ostrinia furnacalis:}

Fekunditas betina, masa inkubasi telur, dan fertilitas telur. Dua puluh imago jantan dan dua puluh imago betina yang keluar dari pupa pada hari yang sama dimasukkan ke dalam gelas plastik dengan diameter $7 \mathrm{~cm}$ dan tinggi $10 \mathrm{~cm}$ untuk dikawinkan pada suhu ruang $\left(25^{\circ} \mathrm{C}\right)$. Kapas yang sudah diresapi dengan larutan madu $10 \%$ diletakkan di dalam gelas plastik sebagai sumber makanan bagi imago. Larutan madu $10 \%$ dipilih karena merupakan pakan yang paling baik untuk meningkatkan fekunditas dan longivitas imago (Nelly dan Buchori 2008). Gelas pemeliharaan diperiksa setiap hari untuk menandai kelompok telur yang telah dihasilkan imago. Kelompok telur ditandai dengan spidol berwarna dengan cara dilingkari. Kelompok telur yang dihasilkan pada hari selanjutnya ditandai dengan warna spidol yang berbeda. Setiap telur pada kelompok telur dihitung dengan bantuan lup dan counter untuk mendapatkan data fekunditas betina. Masa inkubasi telur diketahui dengan cara mencatat tanggal mulai dari telur diletakkan oleh imago hingga telur menetas. Tingkat fertilitas adalah berdasarkan jumlah telur yang menetas.

Masa hidup imago. Nilai longivitas imago didapatkan dari pengamatan siklus hidup stadia imago mulai dari saat imago keluar dari pupa hingga imago mati.

Waktu kopulasi imago. Pengamatan waktu kopulasi imago dilakukan berdasarkan umur dan jam. Dua puluh imago jantan dan dua puluh imago betina yang keluar dari pupa pada hari yang sama masingmasing dipasangkan di dalam gelas plastik dengan diameter $7 \mathrm{~cm}$ dan tinggi $10 \mathrm{~cm}$ untuk dikawinkan. Kapas yang sudah diresapi dengan larutan madu 10\% diletakkan di dalam gelas plastik sebagai sumber 
makanan imago. Pengamatan dilakukan di dalam ruangan gelap dengan suhu ruang $\left(25^{\circ} \mathrm{C}\right)$ setiap satu jam, dimulai saat memasuki fase gelap (scotophase) yaitu pada pukul 18.00-06.00. Umur imago berkopulasi diketahui dengan cara mencatat tanggal saat imago ditemukan berkopulasi. Jam kopulasi imago didapatkan dengan cara mencatat jam saat imago ditemukan berkopulasi. Pengamatan ini dilakukan selama rentang waktu satu minggu sejak pemasangan imago jantan dan betina. Hal ini disebabkan imago $O$. furnacalis masih dapat berkopulasi hingga satu minggu setelah keluar dari pupa (Krismiati 2005).

Analisis Data. Lama siklus $O$. furnacalis diketahui dengan menghitung kisaran lama tiap stadia sehingga didapatkan kisaran siklus hidup secara keseluruhan. Fekunditas betina diketahui dengan menghitung jumlah total telur yang dihasilkan imago betina selama hidupnya. Lama masa inkubasi telur diketahui dengan menghitung kisaran dan rata-rata lama stadia telur hingga menetas. Tingkat fertilitas telur dianalisis dengan menghitung persentase telur yang berhasil menetas terhadap total telur yang dihasilkan. Analisis waktu kopulasi imago dilakukan dengan mencatat waktu imago berkopulasi dan menghitung persentase jumlahnya.

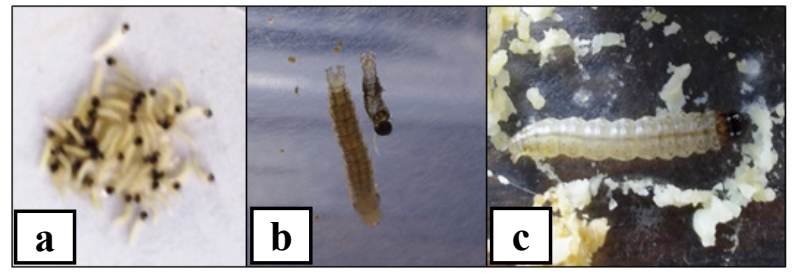

Gambar 4 Larva O. furnacalis (a) larva instar I saat baru keluar dari telur (b) larva instar II setelah berganti kulit menjadi larva instar III (c) larva instar V sebelum menjadi pra pupa.

Tabel 1 Siklus hidup O. furnacalis yang diberi pakan buatan.

\begin{tabular}{lcc}
\hline Stadia & Lama stadia (hari) & $\mathrm{n}$ (individu) \\
\hline Telur & $3-5$ & 2473 \\
Larva & & \\
$\quad$ Instar I & $2-4$ & 21 \\
$\quad$ Instar II & $1-4$ & 21 \\
$\quad$ Instar III & $2-3$ & 21 \\
$\quad$ Instar IV & $2-4$ & 21 \\
$\quad$ Instar V & $2-5$ & 20 \\
Total stadia larva & $11-17$ & 20 \\
$\quad$ Pra Pupa & $1-2$ & 20 \\
Pupa & $5-8$ & 20 \\
Imago & $6-11$ & 40 \\
\hline Total & $27-34$ & 20 \\
\hline
\end{tabular}

\section{HASIL}

Siklus Hidup. Pengamatan siklus hidup $O$. furnacalis meliputi pengamatan stadia telur, larva, pupa, dan imago. Hasil pengamatan menunjukkan bahwa telur menjadi larva setelah 3-5 hari. Telur berwarna bening kekuningan pada saat baru diletakkan imago (Gambar 3a). Bintik-bintik hitam kemudian muncul pada telur, yang merupakan kepala calon larva (Gambar 3b). Telur kemudian menetas menjadi larva instar I (Gambar 3c). Larva terdiri dari lima instar dan berangsung selama 11-17 hari (Tabel 1). Perubahan instar ditandai dengan beberapa ciri, yaitu pergantian kulit, terlepasnya kapsul kepala larva, dan semakin membesarnya ukuran tubuh larva. Larva yang baru menetas atau larva instar I hanya memiliki panjang 1-3 mm dan berwarna putih hampir bening. Panjang larva instar $\mathrm{V}$ dapat mencapai panjang 2,5 $\mathrm{cm}$ dengan warna tubuh kecokelatan (Gambar 4).

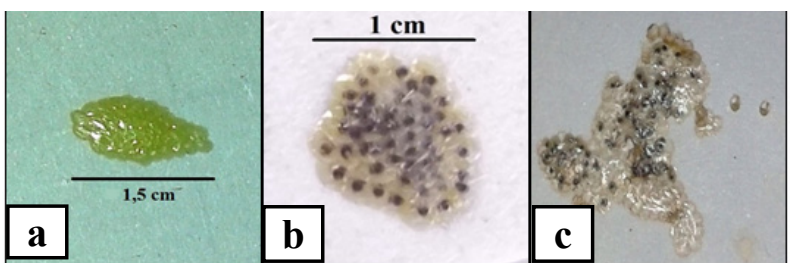

Gambar 3 Telur O. furnacalis (a) Saat baru diletakkan berwarna kekuningan (b) telur berbintik hitam menjelang menetas (c) telur menetas.
Larva kemudian memasuki fase pra pupa selama 1-2 hari. Ciri fase pra pupa adalah perubahan bentuk tubuh larva menjadi mengkerut, memendek, dan melengkung. Fase pra pupa juga dicirikan dengan mulai munculnya benang-benang halus sebagai tahap awal pembentukan pupa. Pupa berukuran kurang lebih $1 \mathrm{~cm}$. Pupa yang masih muda berwarna coklat terang, dan warnanya berubah semakin menghitam menjelang stadia pupa berakhir. Karakter yang membedakan pupa jantan dengan pupa betina yaitu ukuran dan goresan pada ruas abdomen terakhir pupa. Pupa betina berukuran lebih besar dan pada ruas abdomen terakhirnya terdapat goresan menyerupai huruf "V". (Gambar 5b dan 5c). Stadia pupa berlangsung selama 5-8 hari.

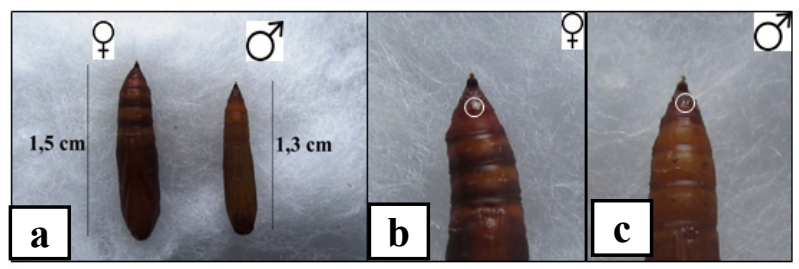

Gambar 5 Pupa $O$. furnacalis (a) pupa betina berukuran lebih besar dan lebar dibandingkan pupa jantan (b) pupa betina dengan ciri goresan berbentuk "V" pada abdomen terakhir (tanda panah) (c) pupa jantan dengan ciri tanpa goresan berbentuk "V" pada abdomen terakhir.

Imago jantan dibedakan dari imago betina berdasarkan warna, ukuran dan bentuk abdomennya. Imago jantan berwarna lebih terang, berukuran 
lebih kecil, dan ujung abdomennya lebih runcing dan menjulur dibandingkan imago betina (Gambar 6a). Panjang imago jantan berkisar antara $1-1,5 \mathrm{~cm}$ dan imago betina berukuran antara 1,3-2 cm. hidup selama 6-11 hari. Sehingga total lama seluruh siklus dari telur hingga imago mati berlangsung selama 27-34 hari. (Tabel 1).

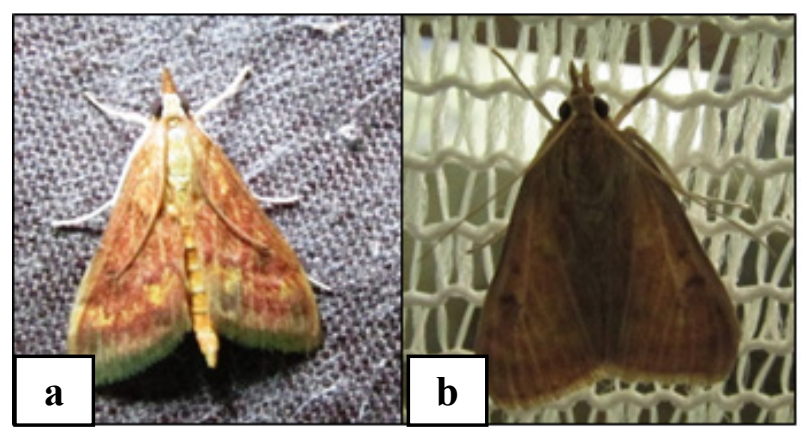

Gambar 6 Imago O. furnacalis (a) ujung abdomen imago jantan terlihat lebih menjulur (tanda panah) (b) ujung abdomen imago betina tidak terlihat menjulur.

Fekunditas Betina, Masa Inkubasi Telur, dan Fertilitas Telur. Ngengat $O$. furnacalis betina menghasilkan telur yang berkelompok dengan jumlah kelompok teluryang berbeda-beda pada masing-masing individu. Berdasarkan pengamatan diketahui bahwa kelompok telur yang dihasilkan berkisar antara 1-5 kelompok telur dengan total kelompok telur berjumlah 56 dan total telur sebanyak 3990 butir. Jumlah telur pada setiap kelompok berkisar antara 16-452 telur (Tabel 2). Lama masa inkubasi telur hingga menetas menjadi larva berlangsung antara 3-5 hari (Gambar 7). Total telur yang dihasilkan 56 kelompok telur yaitu sebanyak 3990 telur, dengan tingkat fertilitas sebanyak 2473 (61,97\%). Dari 2473 telur menetas, sebanyak $1270(51,35 \%)$ telur membutuhkan waktu selama 3 hari untuk menetas dan sebanyak 1043 (42,18\%) membutuhkan 4 hari. Telur yang masa inkubasinya paling lama, yaitu 5 hari, hanya berjumlah $160(6,47 \%)$ (Gambar 7).

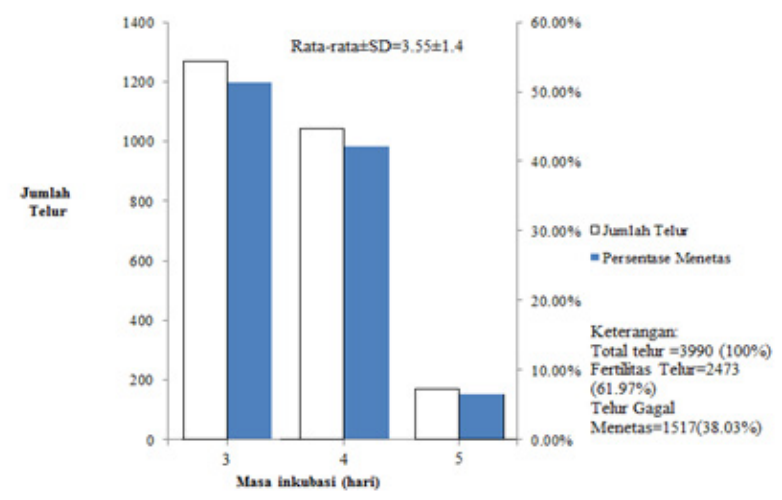

Gambar 7 Masa inkubasi dan fertilitas telur O. furnacalis

Longivitas Imago. Berdasarkan hasil pengamatan yang dilakukan, diketahui bahwa longivitas imago
O. furnacalis berkisar antara 6-11 hari dengan ratarata 9 hari. Jumlah terbesar yaitu sebanyak 17 imago $(42,5 \%)$ berhasil hidup selama 9 hari. Jumlah terkecil yaitu 3 imago (42,5\%) yang hidup selama 7 dan 11 hari (Gambar 8). Longivitas O. nubilalis (penggerek batang jagung eropa sebagai kerabat terdekat $O$. furnacalis) yaitu 11-17 hari dengan rata-rata 13 hari (Fadamiro dan Baker 1999). Longivitas O. nubilalis (penggerek batang jagung eropa sebagai kerabat terdekat $O$. furnacalis) yaitu 11-17 hari dengan ratarata 13 hari (Fadamiro dan Baker 1999). Berdasarkan jenis kelamin imago berhasil diketahui bahwa data hasil imago jantan dan betina $O$. furnacalis memiliki kisaran longivitas yang sama yaitu antara 6-11 hari. Namun nilai rata-rata longivitas imago betina relatif lebih tinggi dibandingkan dengan imago jantan.

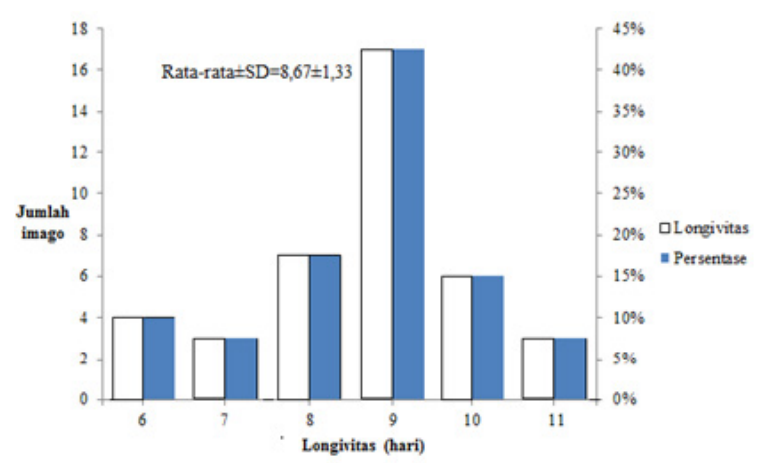

Gambar 8 Longivitas dan persentase longivitas imago $O$. furnacalis.

Tabel 2 Fekunditas imago betina $O$. furnacalis

\begin{tabular}{ccc}
\hline Betina & Jumlah Kelompok Telur & Jumlah Telur \\
\hline 1 & 2 & 54 \\
2 & 3 & 205 \\
3 & 5 & 430 \\
4 & 2 & 92 \\
5 & 3 & 77 \\
6 & 4 & 452 \\
7 & 5 & 542 \\
8 & 2 & 95 \\
9 & 2 & 101 \\
10 & 4 & 267 \\
11 & 1 & 21 \\
12 & 2 & 116 \\
13 & 1 & 16 \\
14 & 2 & 56 \\
15 & 2 & 130 \\
16 & 4 & 378 \\
17 & 4 & 262 \\
18 & 3 & 165 \\
19 & 1 & 85 \\
20 & 4 & 446 \\
\hline Total & 56 & 3990 \\
\hline & &
\end{tabular}


Waktu Kopulasi Imago. Hasil pengamatan menunjukkan bahwa imago melakukan kopulasi pada umur 0 hari (tepat pada hari imago keluar dari pupa) hingga umur 3 hari dengan rata-rata umur yaitu 1,1 hari. Hampir separuh dari total sampel imago yang diuji, atau 8 pasang imago (40\%), berkopulasi pada umur 1 hari setelah imago keluar dari pupa. Hanya 2 pasang imago (10\%) yang melakukan kopulasi pada umur 3 hari setelah imago keluar dari pupa (Gambar 9).

Waktu kopulasi imago berkisar antara jam ke-3 hingga jam ke-8 setelah lampu mati pada scotophase. Jam ke-5 atau pukul 22.00-23.00 merupakan waktu imago paling banyak melakukan kopulasi dengan jumlah 7 pasang (35\%). Jam ke-4 atau pukul 21.00-22.00 merupakan waktu imago paling sedikit melakukan kopulasi dengan jumlah 2 pasang. Pada jam ke-3, jam ke-6 hingga jam ke-8 masing-masing terdapat $3(15 \%)$ pasang imago yang melakukan kopulasi (Gambar 10).

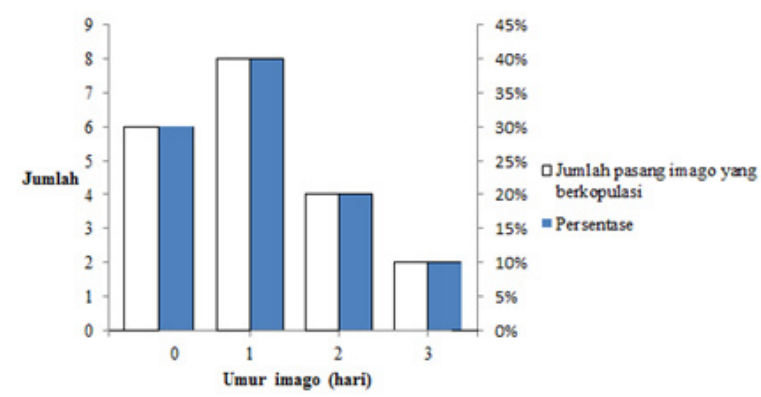

Gambar 9 Waktu dan persentase kopulasi imago O. furnacalis berdasarkan umur.

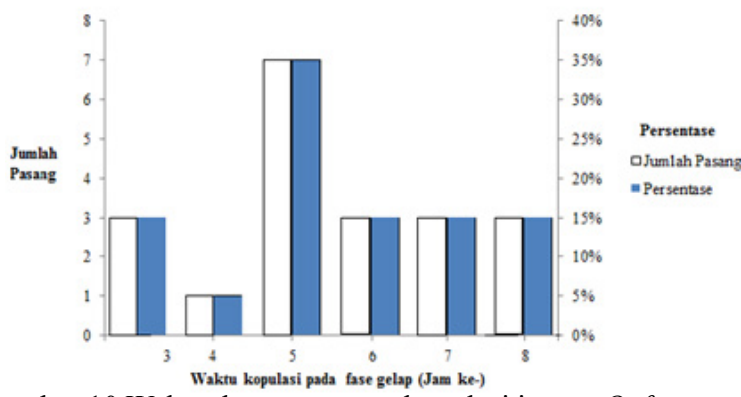

Gambar 10 Waktu dan persentase kopulasi imago O. furnacalis pada fase gelap

\section{PEMBAHASAN}

Apabila dibandingkan dengan siklus yang hidup O. furnacalis yang diberi pakan alami, periode stadia telur hingga stadia pupa pada siklus $O$. furnacalis yang diberi pakan alami berlangsung lebih lama dibandingkan $O$. furnacalis yang diberi pakan buatan. Namun lama hidup stadia imago yang diberi pakan alami berlangsung lebih singkat dibandingkan dengan imago yang diberi pakan buatan (Nonci dan Baco 1991) (Tabel 3).
Tabel 3 Perbandingan siklus hidup O. furnacalis yang diberi pakan buatan dengan yang diberi pakan alami.

\begin{tabular}{lcc}
\hline Stadia & Pakan Buatan & $\begin{array}{c}\text { Pakan Alami } \\
\text { (Nonci \&Baco 1991) }\end{array}$ \\
\hline Telur & 3,55 & 3,6 \\
Larva & & \\
$\quad$ Instar I & 3 & 3,3 \\
Instar II & 2,47 & 3,7 \\
Instar III & 2,14 & 3,8 \\
Instar IV & 2,38 & 3,4 \\
Instar V & 2,9 & 4,7 \\
Pupa & 5,75 & 8,5 \\
Imago & 8,68 & 3,5 \\
\hline
\end{tabular}

Perbedaan pada panjang siklus hidup ini diduga dipengaruhi oleh perbedaan kandungan nutrisi pada pakan buatan yang lebih bervariasi dan lebih mendukung perkembangan serangga dibandingkan dengan pakan alami. Hal ini juga didukung dengan komposisi pakan buatan yang digunakan mengandung berbagai nutrisi tambahan seperti protein, antibiotik, dan vitamin.

Protein merupakan senyawa makromolekul yang terdiri dari asam amino, yang merupakan materi penting untuk pertumbuhan dan perkembangan makhluk hidup. Kandungan protein pada pakan dapat mempengaruhi proses pertumbuhan larva untuk bisa mencapai tahap akhir perkembangannya. Pembentukan jaringan tubuh pada larva yang memakan pakan dengan kandungan protein tinggi akan lebih pesat sehingga larva lebih cepat mencapai tahap instar terakhir (Lestari et al. 2013). Stadia telur hingga pupa yang berlangsung lebih cepat menyebabkan imago keluar lebih cepat dan mempercepat peluang imago melakukan kopulasi.

Kandungan antibiotik pada pakan buatan dapat mengurangi risiko infeksi yang disebabkan oleh bakteri, terutama Bacillus thuringiensis (Bt) (Morton 1979). Dengan ditekannya risiko infeksi Bt tersebut maka jumlah kematian serangga dapat ditekan pula sehingga lama hidup (longivitas) semakin panjang. Lama hidup yang panjang akan menghasilkan jumlah telur yang juga lebih banyak jika dibandingkan dengan yang lama hidupnya pendek (Nelly dan Buchori 2008).

Penelitian lain yang menggunakan $O$. nubilalis sebagai serangga uji menghasilkan rata-rata fekunditas yang lebih besar, yaitu 540 butir telur, namun dengan tingkat fertilitas telur yang tidak terlalu berbeda jauh, yaitu sebesar 64,9\% (Fadamiro dan Baker 1999).

Berdasarkan jenis kelamin imago berhasil diketahui bahwa data hasil imago jantan dan betina $O$. furnacalis memiliki kisaran longivitas yang sama yaitu antara 6-11 hari. Namun nilai rata-rata longivitas imago betina relatiflebih tinggi dibandingkan dengan imago jantan. Kecenderungan bahwa imago betina memiliki 
longivitas yang lebih tinggi dibandingkan imago jantan ini juga ditemukan pada ngengat Nyctemera coleta (Atmaja \& Kilin 1999) dan kepik Rhinocoris fuscipes (Pambudhi 2012).

Imago O. furnacalis melakukan kopulasi segera setelah imago keluar dari pupa. Namun O. furnacalis masih memiliki kemampuan berkopulasi hingga rentang waktu satu minggu setelah imago keluar dari pupa (Kalshoven 1981). Hal ini juga terjadi pada serangga lain, seperti yang ditemukan pada imago betina serangga penggerek buah pada cabai (Helicoverpa armigera), yang masih melakukan perilaku memanggil jantan dan berkopulasi hingga hari ke-4 setelah keluar dari pupa atau saat berumur 5 hari (Hasyim et al. 2013).

Data-data yang didapat dari penelitian ini sangat bermanfaat untuk keberlanjutan penelitian lain yang menggunakan serangga uji $O$. furnacalis, contohnya penelitian untuk mengetahui detail perilaku kawin dan bioekologi $O$. furnacalis dan pengujian tanaman jagung transgenik. Data waktu kawin dapat diaplikasikan untuk meningkatkan akurasi perangkap feromon sintetik serangga sehingga pengendalian $O$. furnacalis yang masih menggunakan insektisida sebagai agen pengendali dapat ditekan. Penelitian ini juga berhasil mengungkapkan bahwa pakan buatan dengan formula yang telah dimodifikasi ini dapat digunakan untuk perbanyakan serangga, dengan hasil perbanyakan yang relatif lebih baik dibandingkan dengan perbanyakan yang menggunakan pakan alami.

Siklus hidup $O$. furnacalis yang diberi pakan buatan secara keseluruhan berlangsung selama 2734 hari. Fekunditas betina yaitu sebanyak 200 butir telur dengan tingkat fertilitas sebesar $61,97 \%$ dan masa inkubasi 3-5 hari. Longivitas imago yaitu selama 6-11 hari, dengan longivitas imago betina lebih tinggi dibandingkan jantan. Imago melakukan kopulasi mulai umur nol hingga tiga hari setelah keluar dari pupa. Waktu imago berkopulasi terbanyak adalah pada jam ke-5 setelah fase gelap dimulai. Pakan buatan yang digunakan pada penelitian ini dapat digunakan untuk perbanyakan $O$. furnacalis, dengan hasil yang relatif lebih baik dibandingkan dengan perbanyakan yang menggunakan pakan alami.

\section{UCAPAN TERIMA KASIH}

Penulis mengucapkan terima kasih kepada kedua orangtua dan pihak keluarga atas dukungan moril selama melakukan penelitian. Penulis juga ingin mengucapkan terima kasih dosen pembimbing atas bimbingan dan bantuannya, termasuk juga kepada rekan-rekan di balai penelitian BB Biogen yang telah banyak membantu dalam penelitian ini, yaitu: Pak Yusup, Pak Wito, Bu Jenab, dan Bu Rafika.

\section{DAFTAR PUSTAKA}

Atmaja WR, Kilin D. 1999. Beberapa aspek biologi ulat belang Nyctemera coleta Cramer (Lepidoptera: Noctuidae) pada daun dewa Gynura procumbens (Lour) Merr. di laboratorium. Di dalam: [PEI] Perhimpunan Entomologi Indonesia Cabang Bogor (ID), editor. Peranan Entomologi dalam Pengendalian Hama yang Ramah Lingkungan dan Ekonomis. Prosiding Seminar Nasional Perhimpunan Entomologi Indonesia; 1999 Feb 16; Bogor, Indonesia. Bogor (ID): Perhimpunan Entomologi Indonesia. hlm 495-500.

Fadamiro HY, Baker C. 1999. Reproductive performance and longevity of female European corn borer, Ostrinia nubilalis: effects of multiple mating, delay in mating, and adult feeding. J Ins Phys. 45(4): 385-392.

Heryana, R. 2013. Penggerek batang jagung Ostrinia furnacalis Guenée (Lepidoptera: Crambidae): Tingkat serangan di wilayah Bogor dan siklus hidupnya di laboratorium [skripsi]. Bogor (ID): Institut Pertanian Bogor.

Hasyim A, Setiawati W, Murtiningsih R. 2013. Perilaku memanggil ngengat betina dan evaluasi respons ngengat jantan terhadap ekstrak kelenjar feromon seks pada tanaman cabai merah. J Hort. 23(1): 72-79.

Kalshoven LGE. 1981. The Pests of Crops in Indonesia. Laan PA van der, penerjemah. Jakarta (ID): Ichtiar Baru-Van Hoeve. Terjemahan dari: De Plagen van de Cultuurgewassen in Indonesie.

Krismiati Y. 2005. Isolasi dan identifikasi senyawa feromon seks imago penggerek batang jagung (Ostrinia furnacalis) dengan kromatografi gas cair [skripsi]. Bogor (ID): Universitas Pakuan.

Lestari S, Ambarningrum TB, Pratiknyo H. 2013. Tabel hidup Spodoptera litura Fabr. dengan pemberian pakan buatan yang berbeda. J Sains Vet. 31(2): 166-179.

Morton AC. 1979. Rearing butterflies on artificial diet. J Res Lep. 18(4): 221-227.

Nelly N, Buchori D. 2008. Pengaruh pakan terhadap lama hidup dan kebugaran imago Eriborus argenteopilosus Cameron (Hymenoptera: Ichneumonidae). J Ent Ind (ID). 5(1): 1-9.

Nishe F. 2012. Perkembangan dan perilaku kawin penggerek batang padi kuning, Scirpophaga incertulas Walker, pada tiga varietas padi [skripsi]. Bogor (ID): Institut Pertanian Bogor.

Nonci N. 2004. Biologi dan musuh alami penggerek batang Ostsrinia furnacalis Guenée (Lepidoptera: Pyralidae) pada tanaman jagung. J Lit Pert. 23(1): 8-14.

Nonci N, Baco D. 1991. Pertumbuhan penggerek batang jagung (Ostrinia furnacalis Guenee.) pada berbagai tingkat umur tanaman jagung (Zea mays L.). Agrikam. 6(3): 95-101.

Pambudhi WR. 2012. Biologi kepik pembunuh Rhinocoris fuscipes (Hemiptera: Reduviidae) [skripsi]. Jember (ID): Universitas Jember.

Rahayu T. 2014. Pembiakan massal dengan pakan buatan untuk memperoleh Ostrinia furnacalis dengan kebugaran lebih tinggi [skripsi]. Yogyakarta (ID): Universitas Gadjah Mada. 